\title{
Brasil, Portugal e Espanha - análise dos serviços de compartilhamento de veículos não motorizados a crianças
}

Brazil, Portugal and Spain - analysis of non-motorized vehicle sharing services for children Brasil, Portugal y España - analisis de los servicios de uso compartido de vehiculos no motorizados para infants

\section{Resumo}

A integração dos veículos não motorizados por compartilhamento está a ganhar destaque nas cidades. Historicamente, o acesso a esses veículos a crianças e famílias com crianças tem falhado sistematicamente. São raros os sistemas de compartilhamento, a nível mundial, que dispõem de veículos adaptados ao transporte de crianças. A partir deste problema, que passa quase despercebido, foram identificadas as origens históricas deste tipo de veículos, as suas características e a presença deste tipo de veículos nas cidades. A nível metodológico, optou-se pela elaboração de um levantamento de experiências existentes, baseada inicialmente em pesquisa documental e complementada com observação in loco, em diferentes cidades de Portugal, Espanha e Brasil. O artigo é ilustrado com fotografias dos diferentes veículos nas várias cidades. Nas fotografias é possível observar o problema central deste trabalho - a falta de condições de acessibilidade aos serviços de transporte não motorizados por compartilhamento em relação às crianças e famílias com crianças.

Palavras-chave: Sistemas de Mobilidade Compartilhada, Problemas de mobilidade compartilhada, micromobilidade, compartilhamento de bicicletas em família, compartilhamento de patinetes, crianças, acessibilidade.

\footnotetext{
Abstract

"Non-motorized shared vehicles" are gaining fans across the country. Historically, the access to these vehicles by children and families has failed. Not all vehicles, worldwide, are designed to transport children. This problem is quite often not even perceived, as the design and characteristics of these vehicles in the cities shown. At the methodological level, it was decided to elaborate a survey of existing experiences, based initially on documentary research and complemented with on-site observation, in different cities in Portugal, Spain and Brazil. The article is illustrated with photographs of the different vehicles in those different cities. In the photographs, it is possible to observe the central problem of this work - which is the lack of accessibility to shared non-motorized transport services in relation to children and families having children.
} 
Key-Words: Shared mobility systems, Shared mobility problems, micromobility, family-friendly bikesharing, scooter sharing, children, accessibility.

\section{Resumen}

La integración de vehículos no motorizados a través del uso compartido, está ganando protagonismo en las ciudades. Históricamente, el acceso a estos vehículos para niños y familias con niños ha fallado constantemente. Los sistemas de intercambio son raros en todo el mundo y cuentan con vehículos adaptados para el transporte de niños. A partir de esta problemática, que pasa casi desapercibida, se identificaron los orígenes históricos de este tipo de vehículos, sus características y la presencia de este tipo de vehículos en las ciudades. A nivel metodológico, se decidió elaborar un levantamiento de experiencias existentes, basado inicialmente en la investigación documental y complementado con la observación in situ, en diferentes ciudades de Portugal, España y Brasil. El artículo está ilustrado con fotografías de los diferentes vehículos en las diferentes ciudades. En las fotografías se puede observar el problema central de este trabajo: la falta de accesibilidad a los servicios de transporte no motorizado de intercambio, relacionado con niños y familias con niños.

Palabras clave: Sistemas de movilidad compartida, Problemas de movilidad compartida, Micro movilidad, Bicicleta familiar compartida, Scooter compartido, Niños, Accesibilidad. 


\section{Introduction}

Cities considered sustainable, inclusive, prosperous, and resilient depend on accessible and healthy means of transport for all people that facilitate safe, efficient, and pollution-free flow. Increasing numbers of cities have adopted non-motorized shared transport services. In this paper, we also consider as nonmotorized shared vehicles the assisted non-motorized vehicles such as bicycles and electric scooters, whose motor works in an auxiliary way to the human traction. In 2017, Robin Chase, with other international partners from the mobility and transportation fields defined in English, Spanish, Italian, French, and Chinese ten principles for shared "mobility" entitled "Shared Mobility Principles for Livable Cities" (CHASE, 2017).

Principle number five of this document, "We promote equity", highlights the importance of physical, digital, and financial access to shared transport vehicles and further mentions that these vehicles should be carefully designed to ensure that its use is possible and accessible to all users regardless of age, gender, race, ethnicity, and financial capacity (CHASE, 2017).

Throughout the world, the experience of childhood has become increasingly urban. In 2007, for the first time, the urban population surpassed the rural population. In 2014 , about $54 \%$ of the world's population already resided in urban areas, and it is estimated that by 2050 , this percentage will increase to $66 \%$, which corresponds to nine billion people residing in medium and large cities, of which 2.7 billion will be children under the age of 18 . As a result, the experience of childhood has become urban and in 2012, this has already been the reality for one billion children (See the United Nations report World Urbanization Prospects: the 2014 revision e Relatório da Situação Mundial da Infância de 2012 cited by Reis, 2015).

According to the document Global Action on Physical Activity 2018-2030 from the World Health Organization (WHO), one in four adults and three in four adolescents (aged 11-17 years) in the world do not currently meet the global recommendations for physical activity set by the WHO. In addition, as countries develop economically, levels of sedentary lifestyles increase. In some countries, sedentary living standards can reach 70 percent, due to changes in transportation patterns, increased use of technology and urbanization. The same document also indicates that levels of physical activity are affected by cultural values. In most countries, girls, women, the elderly, underprivileged groups, and people with disabilities and chronic diseases all have fewer opportunities to access safe, accessible, and appropriate programs and places to become physically active (WORLD HEALTH ORGANIZATION, 2018).

It has been proven that regular physical activity helps prevent and treat non-communicable diseases such as heart disease, stroke, diabetes, breast and colon cancer while also helping to prevent hypertension, overweight, and obesity, in addition to improve mental health, quality of life, and well-being. Along with multiple health benefits, physical activity can also generate additional returns on investment, such as reduced use of fossil fuels, cleaner air, and less congested and safer roads (WORLD HEALTH ORGANIZATION, 2018).

To ensure that everyone achieves these benefits, the same WHO document lists four objectives. The objective number 2, "Create active environments", highlights in all its five points several measures that call for the promotion of connected urban planning and transport policies that can provide space for walking, cycling and other non-motorized transport vehicles (including wheelchairs); the importance of creating infrastructure suitable for all ages; the importance of road prevention and universal access to 
facilities that promote physical activity and also prioritize universal access to all places for pedestrians, cyclists, and public transport.

The non-motorized shared vehicles are increasingly integrated into the definition of "urban mobility" in cities. (MAGALHÃES, 2019, p. 4). According to the author, to talk about urban mobility is important to clarify the concepts of "transportation", "accessibility", and "mobility". Thus, the first concept concerns the intentional movement of material objects. These are movements that are born of human will and for the realization of "transportation" there must be three elements: the subject of transportation, the means of transportation, and the object of transportation. Accessibility is considered to be the ownership of what is accessible, i.e., the one with which a relationship can be established (MAGALHÃES, 2019). Mobility, on the other hand, is related to the property of the object that can be moved by a given transport system and is determined by accessibility.

Not only in Brazil but also in other cities of the world recently begun to be changes in policy towards urban mobility to combat some of the problems of contemporary cities. We are witnessing a reflection on how to offer good conditions of urban mobility to its inhabitants. For Magalhães (2018), one of the greatest challenges in terms of urban mobility in the cities of the future involves the creation of sustainable transport systems. It is important to strengthen the construction and expansion of subway/rail and road corridors. Here we can also include the expansion of spaces for the circulation of non-motorized vehicles such as bicycles. The same author also considers that despite significant advances are underway in urban mobility, gaps remain in the concept of universal accessibility. Many facilities and vehicles impede accessibility for seniors, people with disabilities, or young children. The same is true for the history of non-motorized shared cars that, with few exceptions, do not consider universal access, including children and families with children - the central theme of this paper.

Although most of these vehicles are not adapted for children and families with children, some authors have recognized the importance of using these vehicles. Duran-Rodas and Wulfhorst (2019) state that the general and growing trend of this type of transportation can be associated with positive impacts ranging from reduced greenhouse gas emissions to economic development and health benefits.

That said, we discuss and answer the following questions:

If we should find in all cities non-motorized shared vehicles accessible to all, as the principles of shared mobility state, and if the experience of childhood is increasingly urban, why do we hardly find in cities these vehicles accessible to children and families with children?

Are there any sharing experiences that make the service accessible to children or families with children?

In this paper, we present the history of non-motorized shared vehicles, the access of this type of vehicle to children and families with children, a typological study of this type of vehicle, and some practical examples in different countries.

\section{From Amsterdam to the world - Brief history of sharing experiences of non-}




\section{motorized vehicles}

The shared urban mobility services had their first initiatives in 1948 with car sharing. Later, in 1965, the bike sharing appeared, and more recently in 2012, for the first time in San Francisco, the possibility of sharing scooters (scooter sharing), commonly known as "patinetes" in Brazilian Portuguese (TURONं; CZECH; TÓTH, 2019; KATONA; JUHASZ, 2020).

We can say that bike sharing is the oldest system of non-motorized shared vehicles. Although this system originated in the 1960s of the last century, the growth of bike sharing has progressed slowly until the technology of these vehicles was improved over time. While slow, this growth has resulted in the rapid expansion of bicycle-sharing programs in Europe, and later in most other continents (DEMAIO, 2009).

The first bike sharing projects were founded either by local community organizations, as charitable projects to support the underprivileged, or by bicycle rental companies. Luud Schimmelpennink is a pioneer in the history of bike sharing. According to Velocittà (2014) it was in the 1960s that the Dutch industrial designer created the project "Witte Fietsenplan" (White Bicycle Plan). This project consisted of painting old white bikes and leaving them anywhere in the city of Amsterdam for anybody to use. This was the first urban bike sharing system on record. Although the White Bicycle Plan has been a revolutionary project that changed public transport around the world, it was not implemented as planned and several bicycles were stolen. The White Bicycle Plan had two objectives: to provide free bicycles to any person who needed transportation, and to create opposition to the pollution and dirt produced by cars. The white color of the bicycles symbolized simplicity and hygiene, and thus an alternative to the car and clean for the city.

The evolution of bike sharing can be classified into three distinct generations. The Luud Schimmelpennink' project, which began on July 28,1965 , is classified as the first generation of bike sharing. The second generation occurred in the 1990s, between 1991 and 1993, when Denmark launched two small bike sharing projects in the cities of Farsø, Grenå, and Nakskov that over the course of that decade were enhanced. In England, the Bikeabout program from the University of Portsmouth was launched. In Copenhagen, Denmark, the Bycykler København project was started in 1995 and in 1996, with the support of sponsors, it was disseminated throughout the city. Later, this third generation was improved with electronic lock bicycle locks, telecommunication systems among others. The bike sharing has grown slowly in the following years, and in 1998 France started the Vélo à la Carte program. In 2000, Germany launched in Munique the bike hire system Call a Bike (DEMAIO, 2009).

In Portugal, the Bicicletas de Utilização Gratuita de Aveiro (BUGA) system - in English, Aveiro Free Bikes - started in the year 2000. This system had 350 BUGAS bicycles for free use, accessible at 30 parking places scattered over the city (MOTOR24, 2019). According to the same website, BUGA was a pioneer system in Portugal of bike sharing network that for being so innovative gained great recognition at a national level and passed an image of Aveiro as a bike-friendly city.

In 2005, the city of Lyon in France launched the Velo'v service, with 1,500 bikes. Then in 2007 Paris launched the Vélib' bike sharing, initially with a fleet of 7,000 bicycles that it has expanded over the years and operates both in the center and in the suburbs (DEMAIO, 2009). The author also states that outside of Europe, bike sharing finally started happening in 2008 with new programs in Brazil, Chile, China, New Zealand, South Korea, Taiwan, and the United States of America. Each of these programs were the first third generation bike sharing programs to their countries.

Duran-Rodas and Wulfhorst (2019) state that bike-sharing systems (BSS) are currently divided into three categories: station-based bike sharing (SBBS), free-floating bike sharing (FFBS), and hybrid bike sharing (HBS), which is a mixture of the previous two. The current bike sharing systems also use the Global 
Positioning System (GPS), which enables tracking the bicycle's location in real time, thus decreasing the risk of theft.

Figure 1: The history of bike-sharing divided into three generations

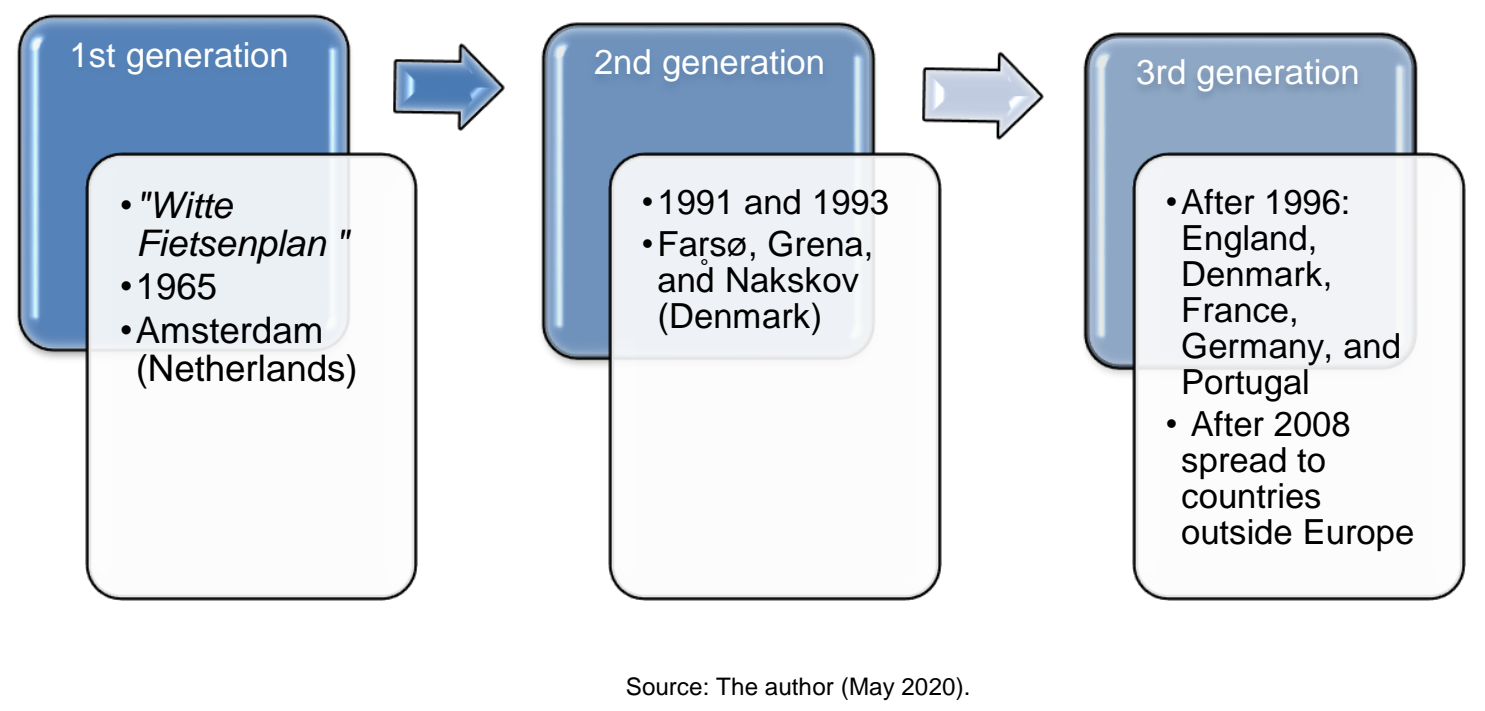

Katona and Juhasz (2020) note that traditional bike sharing systems are used all over the world. The bike sharing systems are based on a fixed coupling network. This type of system works well, but has some gaps, such as only serving the highest density areas of the city, restricting the use of the vehicle fleet to many potential users who are outside these areas. In recent years, some operators have started to develop solutions without the need for fixed stations. The biggest advantage of this system is that the user can leave the bicycle anywhere. Some cities in the world, such as Seattle or Singapore, have adopted the creation of bicycle parking places to avoid this confusion.

Portugal is also implementing bicycle parking. To illustrate these initiatives, we share some examples of bicycle parking spaces in the city of Espinho and a bicycle parking places sign in Vila Nova de Gaia (Figure 2 and Figure 3). Porto has created bicycle parking and dozens of parking spaces for shared electric scooters from the three companies operating in the city, such as Bird, Circ, and Hive, as we can see in Figure 4. 
Figure 2: Bicycle parking spaces at Figure 3: Bicycle parking sign at the the Espinho Train Station, Santo Ovídeo subway station, Portugal Portugal

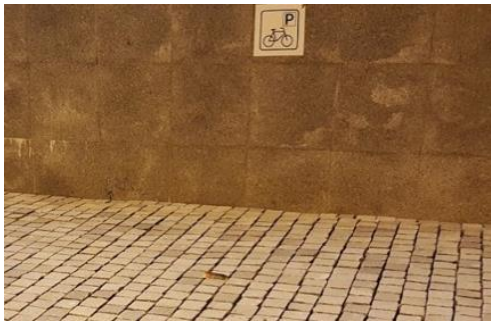

Source: The author (May 2020)

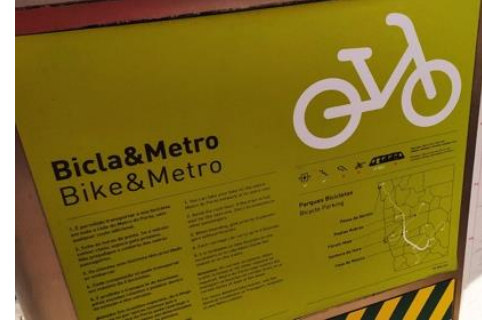

Source: The author (May 2020)
Figure 4: Scooter parking spaces spaces in Porto, Portugal

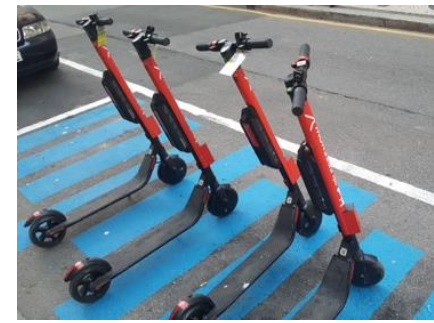

Source: The author (June 2020)

Some of the restrictions of bicycle use are visible on the bicycle parking sign in Figure 3, such as "Passengers without bicycles have priority boarding" and further explains that on special occasions bicycle use may be restricted.

These restrictions can be one of the reasons why we cannot find many bicycle users near of the subway Santo Ovídeo, a reality different from some cities in Europe such as the cities of Mainz or Weimar in Germany, where we see several people on the street using bicycles (see Figure 5 and Figure 6).

Figure 5: Bicycles parked at the train station of Mainz, Germany

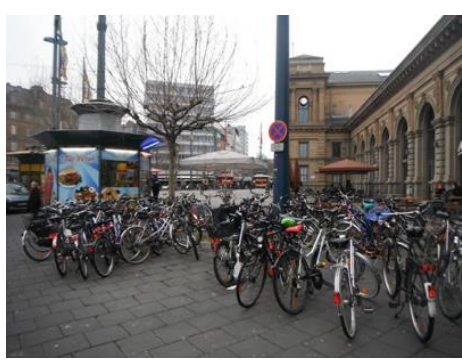

Source: Author (February 2014)
Figure 6: Bicycles parked in the city center of Weimar, Germany

\section{The sharing of non-motorized vehicles nowadays}

According to the Bike Sharing World Map (2020), as of April 2020, there were 17,866,900 bicycles and electric bicycles distributed across 2,102 bike sharing programs, and 385 of these programs were in planning or construction and 474 were no longer in operation.

Graphic 1: Bike-sharing programs around the world

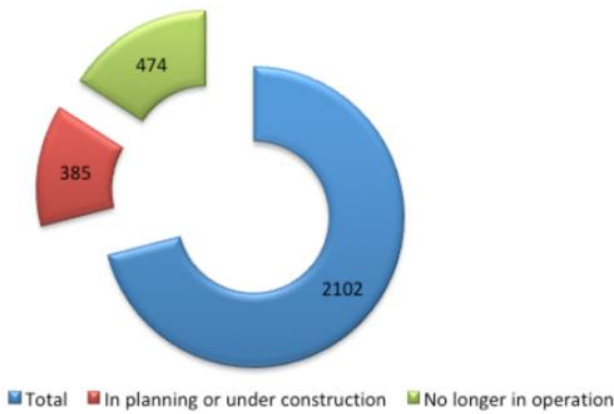

Source: Elaborated by the author (May 2020) based on data from Bike sharing world map (May 2020). 
DeMaio developed the Bike Sharing World Map (Figure 7) in 2007 with the following captions:

Figure 7: Representative cartogram adapted from the Bike Sharing World Map

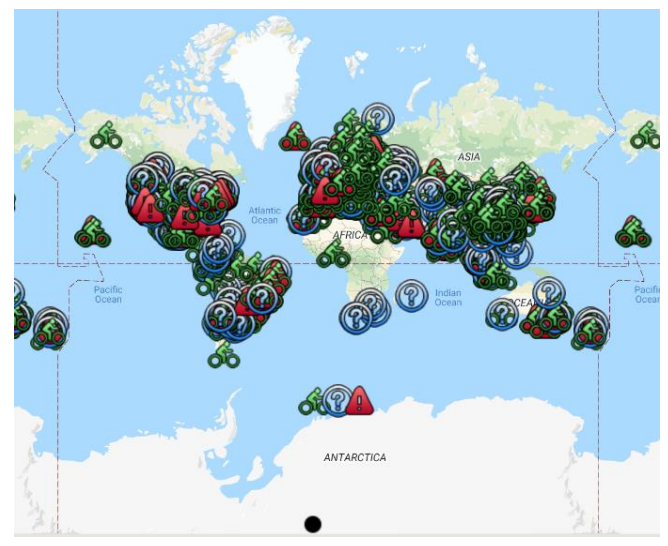

\begin{tabular}{|c|c|}
\hline 유 & A system in operation \\
\hline (8) & A system in planning or construction \\
\hline 0 & A system that is no longer operating \\
\hline & Not listed \\
\hline
\end{tabular}

Source: Bike sharing world map (May 11, 2020).

In the map in Figure 7, it is possible to observe that at 9:07 pm (BST) on May 11, 2020, there were: (i) 432 cities using bike sharing services; (ii) 27,390 people using bike sharing services worldwide; (iii) the 5 cities with more bike sharing in the world: Suzhou \& Wujian with 32,422 vehicles; Weifang with 26,677; Taipei \& Taoyua with 26,580; Hángzhōu with 23,794; and Putian City with 20,618.

Along with China, other countries are also investing in bike sharing. One example is Norway, specifically the city of Oslo. According to Espegren (2019), a leader in urban sharing (technology platform for shared micromobility in Norway), bike sharing in Norway is more successful than among its Scandinavian neighbors. Olso has a strong bike sharing culture, and the shared bike is one of the most popular forms of public transportation in the city. The number of bicycle trips per day in Oslo is eight.This is four times the global standard and one of the best bike sharing rates in the world.

Although the bike is the most well-known non-motorized shared vehicle, other similar shared vehicles, such as scooters, are emerging worldwide. The Global Micromobility Map is a map developed by Alex Rios (Figure 8) which shows the main bike, scooter and moped sharing companies in the world.

Figure 8: Representative cartogram adapted from the Global Micromobility Map

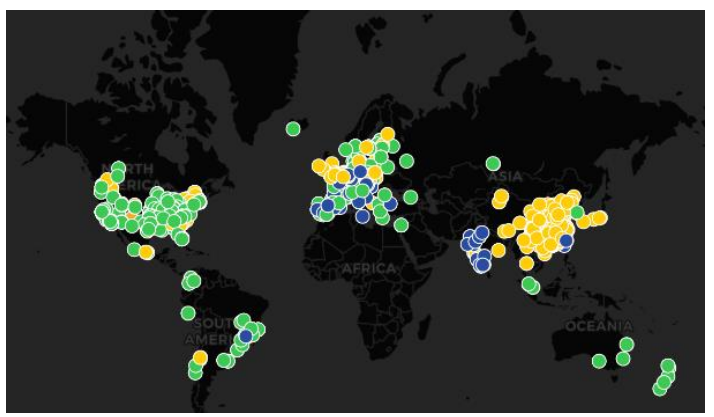

\begin{tabular}{|c|c|}
\hline A yellow & bicycles/eletric bicycles \\
\hline A green & scooters \\
\hline A blue & motorcycles \\
\hline
\end{tabular}

Source: Global Micromobility Map (2020).

Graphic 2: Leading vehicle-sharing companies by type of available vehicle 


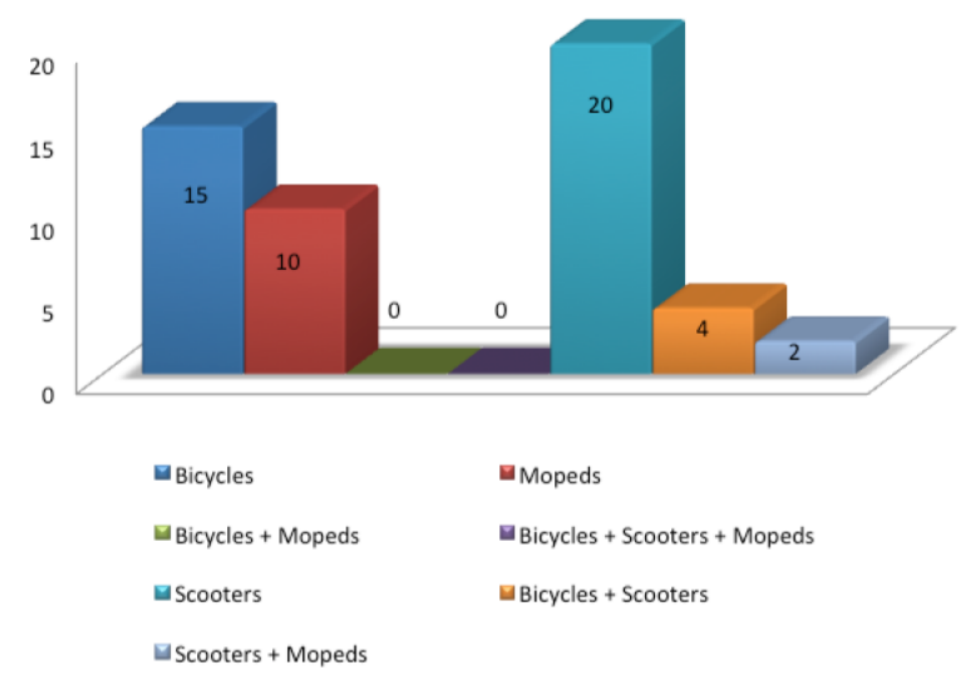

Source: Elaborated by the author (May 2020) based in data from Global Micromobility Map (May 2020).

With the help of the Global Micromobility Map (2020), we identified 51 vehicle-sharing companies considered as major worldwide. Fifteen of these companies is dedicated to bikes and electric bikes sharing, 20 to scooter sharing, 10 to motorcycle sharing, four to scooter and bike sharing, and two to scooters and motorcycles sharing. None of these companies offered three types of shared vehicles and bicycles and motorcycles at the same time. In addition to these 51 well-known companies, we also identified 54 other companies that are not so famous: 13 bike and electric bike companies, 25 scooter companies, and 16 motorcycle companies.

\section{The sharing of non-motorized vehicles with a focus on children and families with children: Survey of experiences in Brazil, Spain, and Portugal}

These data are significant and show that non-motorized vehicle sharing systems are increasingly common around the world. However, are most of these systems adapted to children and families with children?

\subsection{Methodological comments}

To answer the question raised above, we chose to elaborate a survey of existing experiences, based initially on documentary research and complemented by on-site observation in cities distributed in three countries: Brazil - Brasília and Rio de Janeiro, Spain - Madrid, Portugal - Gaia, Porto, Aveiro, and Lisbon. The criterion used to select cities was the feasibility of the site visit.

In each city visited, the following procedures were performed: (i) observe the public space; (ii) photograph the non-motorized shared vehicles found; (iii) collect information about the service provided.

The planned activities were completed between November 2019 and March 2020. The COVID-19 pandemic has affected the continuity of fieldwork. On May 2020, we try to do a new data collection, but it was not possible because the possibilities of displacement in public space were quite restricted in terms of geographical distance and dwell time, as well as non-motorized shared vehicles were no longer on the streets. In June and July, a new attempt was made to find shared vehicles in Porto (Portugal) and we found some that had recently been placed.

We identified 21 non-motorized vehicle sharing systems and took over 50 photographs.

\subsection{Conditions of accessibility to non-motorized transport sharing services in relation to children and families with children: Documentary research of vehicles and experiences}


During the documentary research, we identified some examples of non-motorized vehicle sharing with the possibility of transporting children and that allow us to consider three distinct situations: 1) Children old enough to use these services without the presence of an adult; 2) Children too big to be transported as a regular passenger, but too young to use these types of services; 3 ) Children who can be transported as a regular passenger on a cargo bike, bicycle seat, or trailer.

In recent years, have emerged reflections on how to make non-motorized vehicle sharing more accessible to all people, regardless of the region where they live or their financial capacity, and how to make it more accessible to people with different physical needs as well. The introduction of electric bike sharing, the use of dockless bikes, and the growth of other non-motorized sharing vehicles have contributed to more and more people around the world being able to use these services. According to the American Association of Retired Persons (2018), the introduction of electric bicycles has expanded access to vehicle sharing services to older motorcyclists, for example. Dockless bike sharing can be an alternative to public transportation, reducing commute times and providing more free time for people (DIJST; VIDAKOVIC, 2000 apud CHEN; ETTEMA; LIEROP, 2020). On the other hand, the authors state that dockless bike sharing may also exclude some population groups such as the elderly, people with disabilities, or those who have no smartphones.

The introduction of shared bikes adapted for people with disabilities in the United States has made it possible, albeit on a small scale, for cyclists to ride with their arms, for example. In Portland, several cyclists lobbied the government to create a bike sharing system adapted to people with disabilities; they also realized the need for bikes with wheelchair storage capacity and assistance at sharing stations (COLLINS, 2018; MERCHANT, 2019). The Adaptive BIKETOWN is a bike sharing program from Portland. The project offers 17 types of adaptive bicycles to people with different needs and pedalling styles. In addition, the Adaptive BIKETOWN provides accessories including helmets, store mobility devices during commuting time, and a pet box.

Whilst every effort is made to promote the access to sharing vehicles, few cities in the world address the issue of family cycling. Many people already use non-motorized vehicle sharing services, but often families cannot use these services as an option to the car in their daily routines, for example, to take the children to school. Depending on the age of the child, family cycling may require the use of several bikes together or one or several adults cycling with younger children sitting in some proper seat, trailer or other cargo bike accessory. However, most systems are not configured to allow or encourage such use, because of age restrictions, lack of bicycles or suitably sized accessories, or legal logistic constraints. Some people wanted to carry child carrier accessories with them to put on their bikes, but the bike sharing systems do not allow. In 2014, a father decided to build his own seat to carry children on shared bikes from the Capital Bikeshare system in Washington, D.C., but the system went against that idea (MERCHANT, 2019).

As will be seen further, in the results of the on-site research, it was possible to verify in practice these difficulties of transporting a child in non-motorized vehicle sharing systems. After all, what options are available to families? Is there space to allow non-motorized vehicle sharing with options to include seats or trailers to take the children? Are there vehicles suitable for the needs of children? What bike sharing options exist for families?

Bike sharing systems suitable for children are rare. Moreover, the programs found are very small or pilot programs. We identified only three options for transporting children: cargo-bike-sharing (CBS), in which 
you can transport children, groceries, or other adult; bicycles suitable for children; and bicycles with a child seat.

According to Merchant (2019), Carvelo2go is the largest cargo bike sharing program (eCargo-bike sharing). This initiative operates in cities across Switzerland without a bike parking or bike station. Carvelo2go makes 300 high-quality electric bicycles available for rent on its digital platform. In Table 1, we describe the characteristics of the five main available models on the Carvelo2go website a (CARVELO2GO, 2020).

Table 1: Information on the characteristics of the Carvelo2go cargo bike system

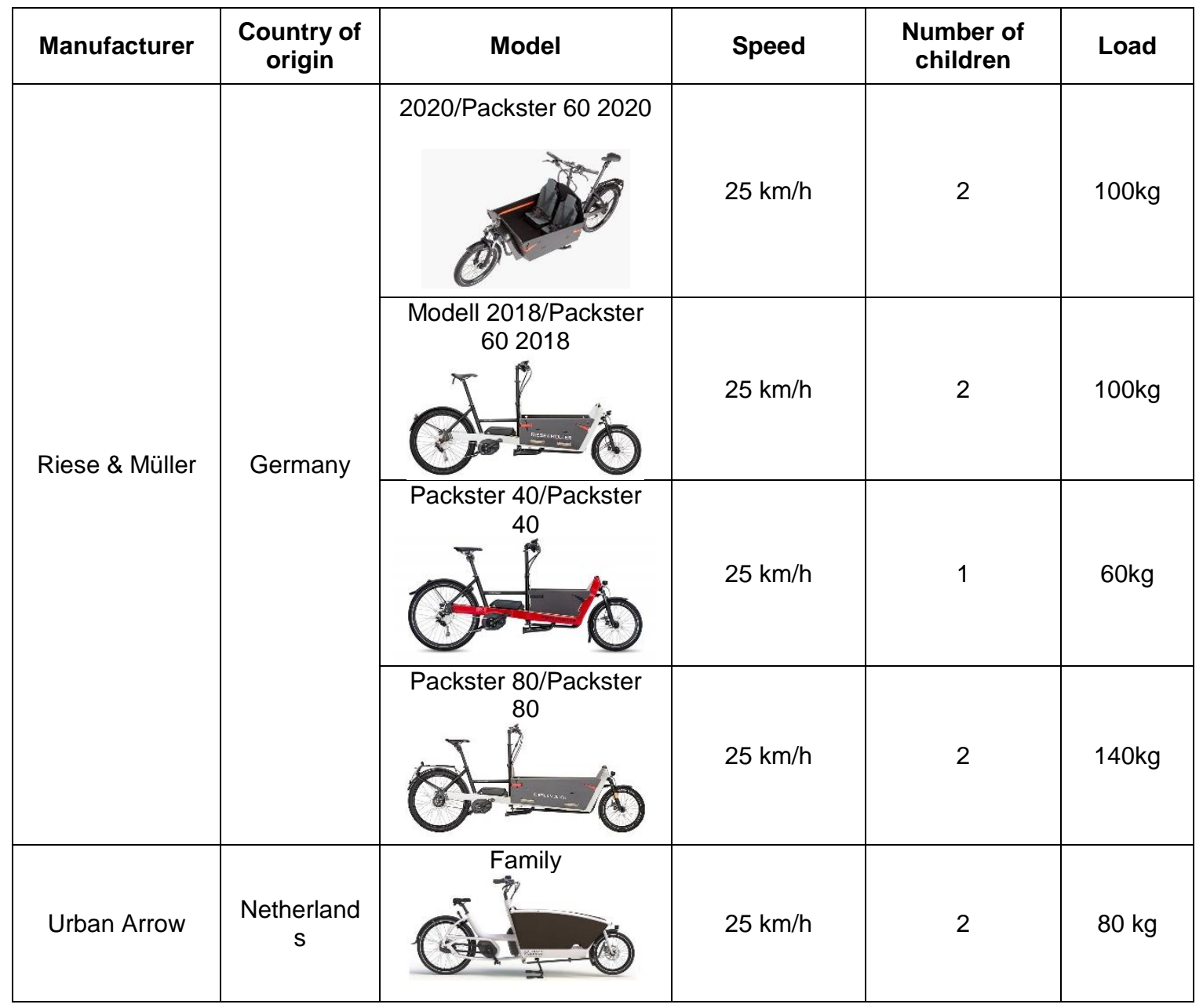

Source: Elaborated by the author (June 2020) based on data and photos available on the Carvelo2go site (June 2020).

According to Merchant (2019), in Germany there is also a cargo bike sharing system to transport children with a fleet of about 60 vehicles. This system is the Transportrad Initiative Nachhaltiger Kommunen (TINK). The TINK initiative operates in the cities of Konstanz and Norderstedt (TINK, 2020). In Konstanz, we found 26 bicycles, specifically 17 Cargo Long with 2 wheels and capacity to carry two children up to 6 years old, and 9 Cargo Trike with three wheels and capacity to carry four children up to 6 years old. Both versions are from a Dutch company called Bakfiets.nl. Currently, this system has become part of the Fahrrad-Mietsystem konrad der Stadtwerke Konstanz - a bike sharing system operating in the city (STADTWERKE KONSTANZ, 2020).

Table 2: Information on the characteristics of the TINK cargo bike system in Konstanz 


\begin{tabular}{|l|l|l|l|l|l|l|l|}
\hline Konstanz & Manufacturer & $\begin{array}{l}\text { Country } \\
\text { of origin }\end{array}$ & Model & $\begin{array}{l}\text { Number of } \\
\text { bicycles }\end{array}$ & $\begin{array}{l}\text { Number of } \\
\text { children }\end{array}$ & Load & $\begin{array}{l}\text { Other } \\
\text { characteristics }\end{array}$ \\
\cline { 3 - 7 } & Bakfiets.nl. & $\begin{array}{l}\text { Netherla } \\
\text { nds }\end{array}$ & $\begin{array}{l}\text { Cargo } \\
\text { Long }\end{array}$ & 17 & $\begin{array}{l}2 \text { children up to } \\
6 \text { years old }\end{array}$ & $180 \mathrm{~kg}$ & $\begin{array}{l}2 \text { wheels, box } \\
\text { between the } \\
\text { handlebar and } \\
\text { the front wheel; } \\
\text { seat belts; } \\
\text { foldable seats; } 2 \\
\text { beverage boxes. }\end{array}$ \\
\cline { 3 - 6 } & & & $\begin{array}{l}\text { Cargo } \\
\text { Trike }\end{array}$ & 9 & $\begin{array}{l}\text { 3 children up to } \\
\text { wheels, box } \\
\text { between the } \\
\text { handlebar and } \\
\text { the front wheel; } \\
\text { seat belts; } \\
\text { foldable seats; } 2 \\
\text { drink box. }\end{array}$ \\
\hline
\end{tabular}

Source: Elaborated by the author (June 2020) based on data from Merchant (2019).

In Norderstedt, 24 cargo bikes and 15 electric transport bikes are available in the following versions:

- Two wheel cargo bike with space for two drink box;

- Three wheel cargo bike with space for four drink box;

- Two wheel cargo bike with engine booster.

Each bike has subtle differences, a height-adjustable saddle, folding seats with seat belts, and the capacity to transport two children under 6 years old (NEXTBIKE, 2020).

In addition to these models of cargo bikes for transporting children, we identified three countries that have very limited pilot projects of bikes in smaller sizes for children: France, Italy, and Brazil. In France, the project seems to be already extinct. To find this type of project, we did a Google search for "scooter sharing family friendly", "bike sharing family friendly", "bike sharing for kids", among other similar concepts or the same words in different languages.

Table 3: Bike share system of smaller size to children

\begin{tabular}{|c|c|c|c|c|c|c|c|}
\hline $\begin{array}{c}\text { City } \\
\text { /Country }\end{array}$ & Name & $\begin{array}{c}\text { Start } \\
\text { date }\end{array}$ & Fleet & $\begin{array}{c}\text { Bike } \\
\text { station }\end{array}$ & $\begin{array}{c}\text { Accessorie } \\
\text { s }\end{array}$ & Users & $\begin{array}{c}\text { Ceased to } \\
\text { operate }\end{array}$ \\
\hline $\begin{array}{c}\text { Paris, } \\
\text { France }\end{array}$ & P'tit Vélib' & $06 / 18$ & 300 & 5 & $\begin{array}{c}\text { helmets, } \\
\text { removable } \\
\text { training } \\
\text { wheels, } \\
\text { basket }\end{array}$ & $\begin{array}{c}4 \text { versions: } \\
\text { "La } \\
\text { Draisienne" } \\
\text { children from 2 } \\
\text { to 4 years } \\
\text { without pedals; } \\
\text { "12 Pouces" } \\
\text { children from 3 } \\
\text { to 5 five years } \\
\text { old with } \\
\text { removable } \\
\text { training } \\
\text { wheels; } \\
\text { "16 Pouces" } \\
\text { children from 5 } \\
\text { to 7 years old } \\
\text { with } \\
\text { removable } \\
\text { training } \\
\text { wheels; } \\
\text { "20 Pouces" } \\
\text { children age 8 } \\
\text { years without }\end{array}$ & \\
\hline
\end{tabular}




\begin{tabular}{|c|c|c|c|c|c|c|c|}
\hline & & & & & & $\begin{array}{l}\text { training } \\
\text { wheels. }\end{array}$ & \\
\hline $\begin{array}{c}\text { Fortaleza, } \\
\text { Brazil }\end{array}$ & $\begin{array}{c}\text { Mini } \\
\text { Bicicletar }\end{array}$ & $\begin{array}{l}07 / 02 \\
2017\end{array}$ & 50 & 5 & $\begin{array}{c}\text { retractable } \\
\text { training } \\
\text { wheels, horn }\end{array}$ & $\begin{array}{c}\text { Children from } \\
3 \text { to } 10 \text { years } \\
\text { old up to } 50 \mathrm{~kg} \\
\text { and up to } 1.50 \\
\text { meters. }\end{array}$ & In operation \\
\hline $\begin{array}{l}\text { São Paulo, } \\
\text { Brazil }\end{array}$ & $\begin{array}{c}\text { Danoninho } \\
\text { Bike Kids } \\
\text { Santos }\end{array}$ & $\begin{array}{l}10 / 30 \\
2016\end{array}$ & 50 & 5 & $\begin{array}{l}\text { retractable } \\
\text { training } \\
\text { wheels }\end{array}$ & $\begin{array}{c}\text { Children from } \\
3 \text { to } 10 \text { years } \\
\text { old up to } 50 \mathrm{~kg} \\
\text { and up to } 1.50 \\
\text { meters. }\end{array}$ & $?$ \\
\hline $\begin{array}{c}\text { Brasília, } \\
\text { Brazil }\end{array}$ & $\begin{array}{l}\text { Mais bike } \\
\text { kids }\end{array}$ & $\begin{array}{l}06 / 17 \\
2018\end{array}$ & 10 & 1 & $\begin{array}{l}\text { retractable } \\
\text { training } \\
\text { wheels }\end{array}$ & $\begin{array}{c}\text { Children from } \\
3 \text { to } 10 \text { years } \\
\text { old up to } 50 \mathrm{~kg} \\
\text { and up to } 1.50 \\
\text { meters. }\end{array}$ & In operation \\
\hline $\begin{array}{c}\text { Goiânia, } \\
\text { Brazil }\end{array}$ & $\begin{array}{l}\text { Gyndebike } \\
\text { KIDS }\end{array}$ & $\begin{array}{l}09 / 09 \\
2019\end{array}$ & $?$ & 2 & $\begin{array}{l}\text { retractable } \\
\text { training } \\
\text { wheels }\end{array}$ & $\begin{array}{c}\text { Children from } \\
3 \text { to } 10 \text { years } \\
\text { old up to } 50 \mathrm{~kg} \\
\text { and up to } 1.50 \\
\text { meters. }\end{array}$ & $?$ \\
\hline $\begin{array}{l}\text { Espírito } \\
\text { Santo, } \\
\text { Brazil }\end{array}$ & $\begin{array}{c}\text { Bike Vitória } \\
\text { Kids }\end{array}$ & $\begin{array}{l}10 / 12 \\
2017\end{array}$ & 30 & 3 & $\begin{array}{l}\text { retractable } \\
\text { training } \\
\text { wheels, } \\
\text { adjustable } \\
\text { saddle and } \\
\text { handlebar }\end{array}$ & $\begin{array}{l}\text { Children up to } \\
50 \mathrm{~kg} \text { and up } \\
\text { to } 1.50 \text { meters. }\end{array}$ & $?$ \\
\hline $\begin{array}{l}\text { Espírito } \\
\text { Santo, } \\
\text { Brazil }\end{array}$ & Bike Serra & $\begin{array}{l}03 / 29 \\
2019\end{array}$ & 20 & 2 & $\begin{array}{l}\text { retractable } \\
\text { training } \\
\text { wheels }\end{array}$ & $\begin{array}{c}\text { Children up to } \\
10 \text { years old } \\
\text { and up to } 1.50 \\
\text { meters. }\end{array}$ & $?$ \\
\hline $\begin{array}{l}\text { Recife, } \\
\text { Brazil }\end{array}$ & $\begin{array}{c}\text { Bike Kids } \\
\text { Recife }\end{array}$ & $\begin{array}{l}10 / 09 \\
2018\end{array}$ & 20 & 2 & $\begin{array}{l}\text { retractable } \\
\text { training } \\
\text { wheels }\end{array}$ & $?$ & $?$ \\
\hline Milan, Italy & $\begin{array}{l}\text { Junior } \\
\text { BikeMi }\end{array}$ & $\begin{array}{l}04 / 30 \\
2016\end{array}$ & 60 & 11 & $?$ & $\begin{array}{c}\text { Children from } \\
6 \text { to } 10 \text { years } \\
\text { old up to } 40 \\
\text { kg. }\end{array}$ & $?$ \\
\hline
\end{tabular}

Source: Author (June 2020).

In Table 3, we summarize the nine small-size bike-sharing projects for children that emerged between 2014 and 2019: one project in France, one project in Italy, and seven projects in Brazil. Most of the projects had a very small fleet consisting of 10 to 50 bicycles distributed between one to five stations. The largest fleets are concentrated in Paris (France), with 300 bikes, and in Milan (Italy) with 60 bikes. The Parisian project was the only one to present bicycles of various sizes and characteristics depending on the age of the children. Although it was the biggest project, it was ended in 2017. In Brazil, the bikes were similar from one city to another. In Italy, the children's bikes were also all the same, and we discovered on the Junior BikeMi website that, in addition to the child-sized bikes, there was also a fleet of 150 shared electric bikes for adults with a seat to carry children up to $20 \mathrm{~kg}$ - "La bici con il seggiolino". 
Junior BikeMi is the world's first integrated bike system for children and adults. For each adult bike, it was possible to rent up to three children's bikes simultaneously.

The following are images of some of the cases studied.

Figure 9: P'tit Vélib' (Paris, France)

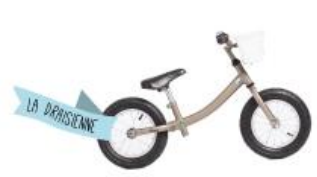

Source: P'tit Vélib/Marketing.

Figure 10: Mini Bicicletar (Fortaleza - CE, Brazil)

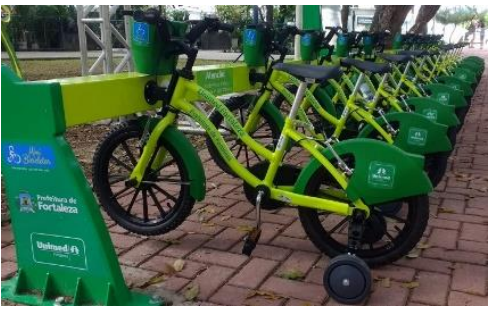

Source: Mini Bicicletar/ Marketing.
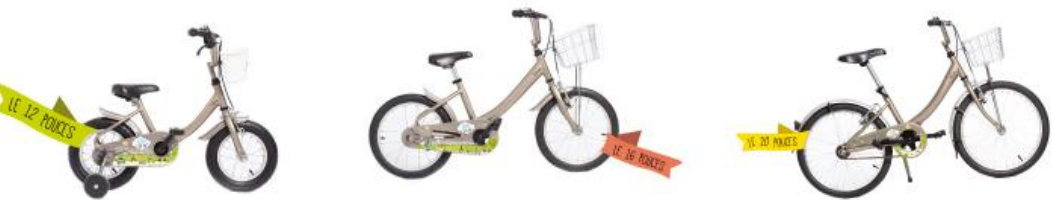

4.3 Conditions of accessibility to the non-motorized transport shared services in relation to children and families with children: A survey in the cities of Brazil, Spain, and Portugal In Table 4, we present the bike sharing systems identified in the cities visited and its main characteristics.

Table 4: Information on the vehicle sharing companies listed in the cities visited

\begin{tabular}{|c|c|c|c|c|}
\hline Country & City & System/Company & Type of vehicle & $\begin{array}{l}\text { Adapted to children/families } \\
\text { with children }\end{array}$ \\
\hline \multirow[t]{5}{*}{ Brazil } & \multirow[t]{3}{*}{ Brasília } & Mais Bike & Bikes & $\begin{array}{c}\text { Yes, in the +Bike Kids version } \\
\text { (bikes in small size with training } \\
\text { wheels) }\end{array}$ \\
\hline & & Yellow & Bikes and scooters & No \\
\hline & & Grin & Scooters & No \\
\hline & \multirow{2}{*}{$\begin{array}{l}\text { Rio de } \\
\text { Janeiro }\end{array}$} & Lime & Scooters & No \\
\hline & & Bike Itaú | Tembici & Bikes & No \\
\hline \multirow[t]{4}{*}{ Portugal } & \multirow[t]{4}{*}{ Lisboa } & Jump by Uber & Bikes and scooters & No \\
\hline & & Lime & Scooters & No \\
\hline & & Gira & Bikes & No \\
\hline & & Hive & Bikes and scooters & No \\
\hline
\end{tabular}




\begin{tabular}{|c|c|c|c|c|}
\hline & & Frog & Scooters & No \\
\hline & & Circ & Scooters & No \\
\hline & $\begin{array}{c}\text { Miramar - } \\
\text { Gaia }\end{array}$ & Circ & Scooters & No \\
\hline & \multirow[t]{3}{*}{ Porto } & Bird & Scooters & No \\
\hline & & Circ & Scooters & No \\
\hline & & Hive & Scooters & No \\
\hline & Aveiro & BUGA & Bikes & $\begin{array}{l}\text { Yes, in the version with child } \\
\text { seat up to } 26 \mathrm{~kg} \text { or with baby } \\
\text { seat to children from } 1 \text { to } 2 \\
\text { years old. }\end{array}$ \\
\hline \multirow[t]{5}{*}{ Spain } & \multirow[t]{5}{*}{ Madrid } & MyGo Wheels & Without a defined name & No \\
\hline & & Jump by Uber & Scooters & No \\
\hline & & Wind & Scooters & No \\
\hline & & Mobike & Bikes & No \\
\hline & & EMT Madrid & Bikes & No \\
\hline
\end{tabular}

Source: Author (November 2019 to June 2020).

Lime was the only company that existed both in Europe, in Lisbon, and in Brazil, in Rio de Janeiro. Jump by Uber was active in the two neighboring countries: Portugal and Spain. Circ operated in the three Portuguese cities listed in Table 4: Lisbon, Porto, and Vila Nova de Gaia. Madrid was the only city that had a new and still nameless sharing vehicle, similar to a scooter but with a seat to travel.

Despite the different non-motorized vehicle sharing companies existing in these cities, only two of them had vehicles to transport young children: the Mais Bike project in Brasília and BUGA system in Aveiro. The Mais Bike has a parallel project called Mais Bike Kids that have a fleet of bikes with training wheels. The free system BUGA offers three bikes with a child seat for children up to $26 \mathrm{~kg}$, one bike with a baby seat for 1 and 2 years old, a kid's bike helmet, and the possibility to put a seat on other bicycles.

On the streets of Brasília, we did not find any bikes of the Mais Bike Kids. However, we did an informal research on the Mais Bike Kids' website and a phone contact with the company in May 2019 and, as a result, we discovered that the bikes for children was still available, but with a very limited fleet.

In Spain, we have identified some vehicle sharing systems that accepts children over 14 or 15 years of age, but they need an application registration performed by their legal guardian. The legal guardian will have to take full responsibility for the actions of minors while using the service.

We conjecture three reasons why non-motorized vehicle sharing services are not accessible to children and families with children. The first is the lack of accessories, such as trolley, child seats, or croup. The second is that in most systems the vehicles have only the same standard size. The legal minimum age 
allowed for the use of these services is the third. These reasons should be studied in future work on the subject. To corroborate this information, we present here photos taken during fieldwork. With the exception of the photo from Aveiro, in all other photos, regardless of the country, we observed the absence of accessories adapted for transporting children and vehicles of different sizes.

\section{Brasília}

Figure 13: Mais Bike bicycle

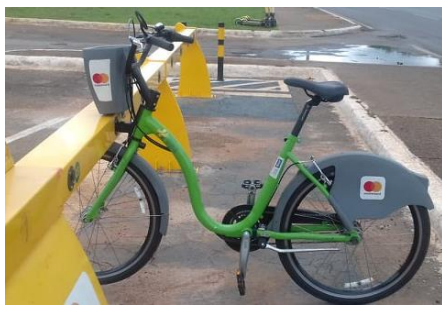

Source: Autor (November 2019)
Figure 14: Yellow bicycle

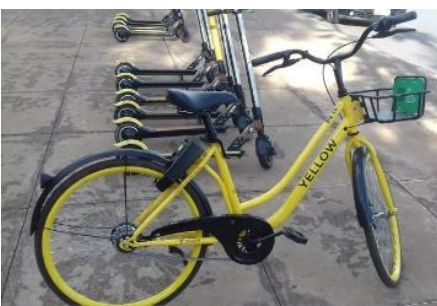

Source: Author (November 2019).
Figure 15: Grin and Yellow scooters

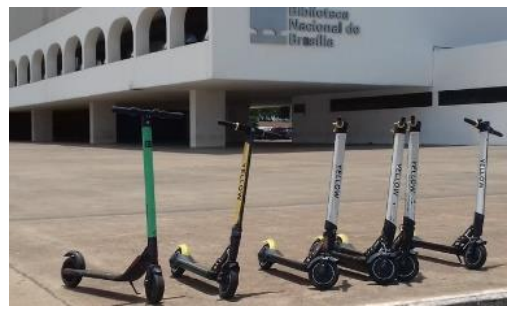

Source: Author (November 2019)

\section{Rio de Janeiro}

Figure 16: Lime scooter

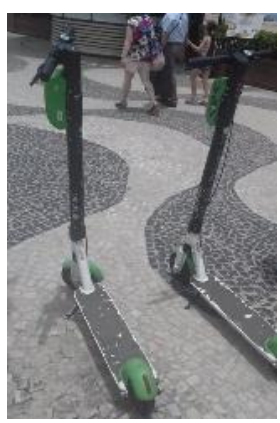

Source: Author (December 2019).

\section{Lisboa}

Figure 18: Jump Uber

scooters and bicycles

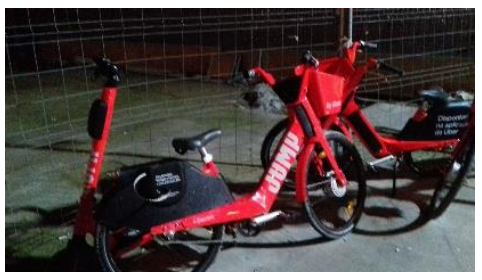

Source: Author (December 2019).

Figure 21: Hive scooters

and bicycles

Figure 17: Bike Itaú | Tembici bicycle

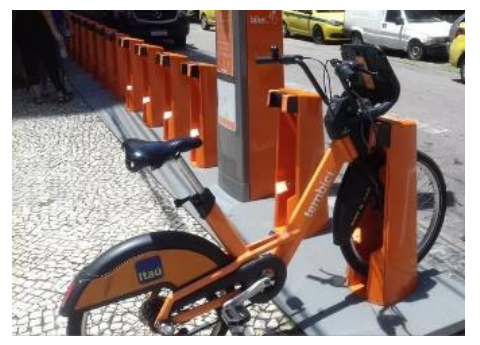

Source: Author (December 2019)

Figure 19: scooter

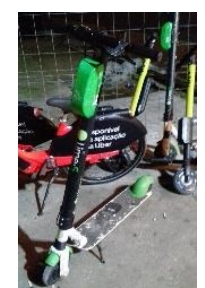

Source: Author (December 2019).

Figure 22: Frog scooters
Figure 20: Gira bicycles

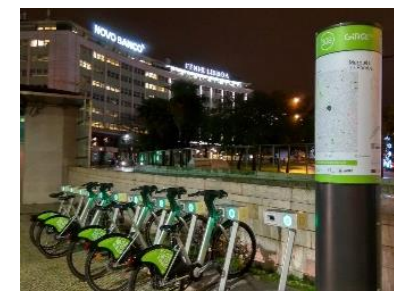

Source: Author (December 2019).

Figure 23: Circ scooters 


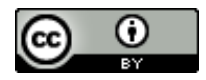

Licensed under a Creative Commons

Attribution International License.
Cadernos de Arquitetura e Urbanismo | Paranoá 30

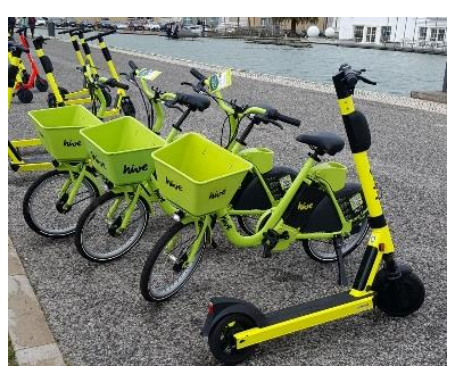

Source: Author (March 2020).

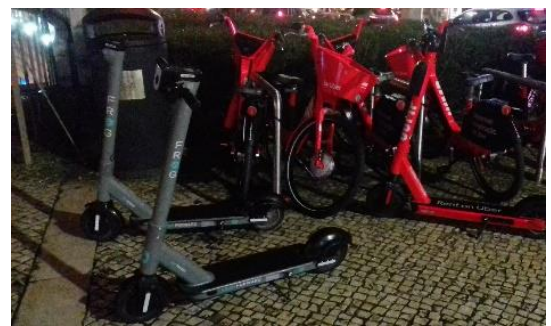

Source: Author (December 2019).

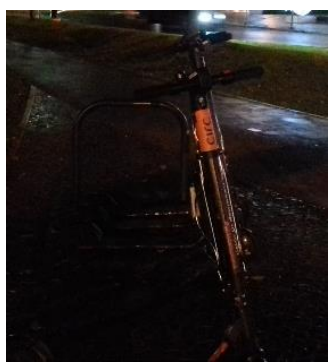

Source: Author (December 2019)

\section{Gaia and Porto}

Figure 24: Circ scooters

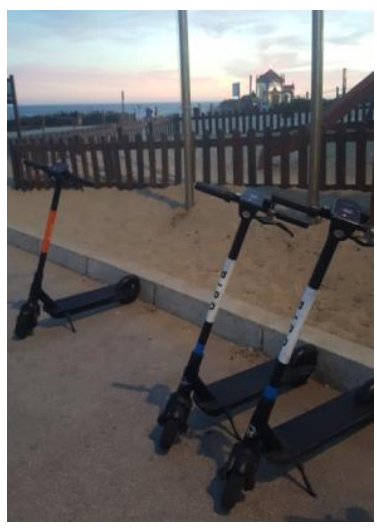

Source: Author (July 2020).
Figure 25: Wive scooters

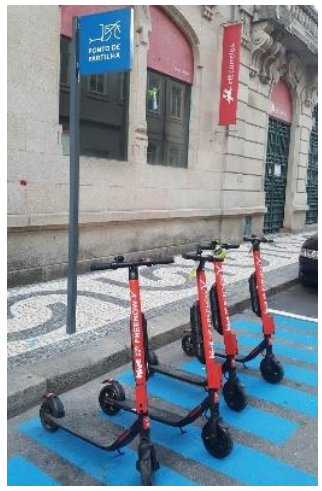

Source: Author (July 2020).
Figure 26: Wive scooters

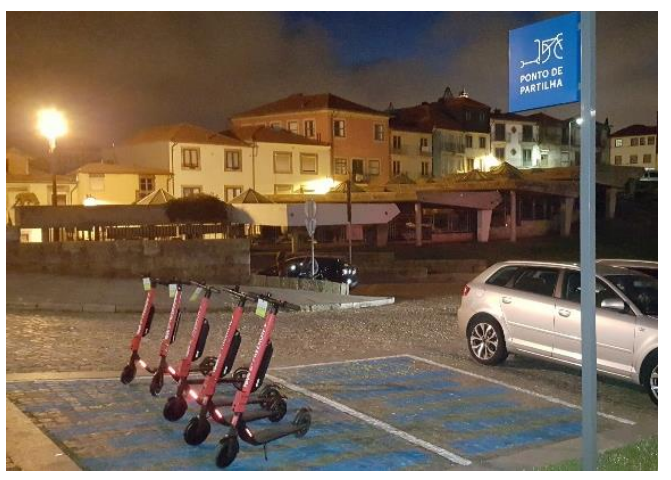

Source: Author (July 2020).

\section{Aveiro}

Figure 27: BUGA bicycle 


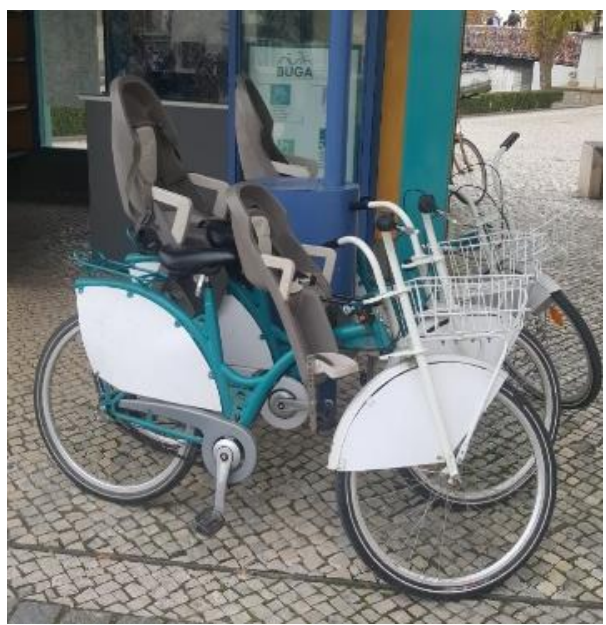

Source: Author (August 2020)

\section{Madrid}

Figure 28: Jump uber scooter, Wind scooter and My Go Wheels vehicle without name

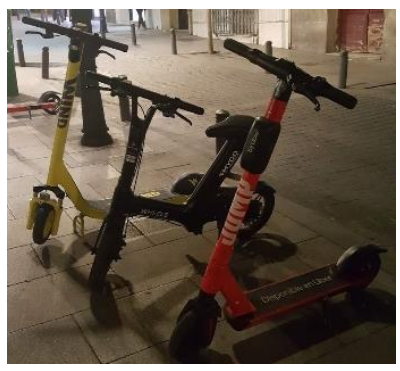

Source: Author (February 2020).
Figure 29: Mobike bicycles

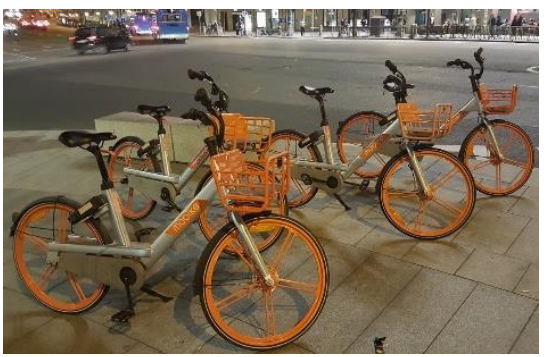

Source: Author (February 2020).
Figure 30: EMT Madrid bicycles

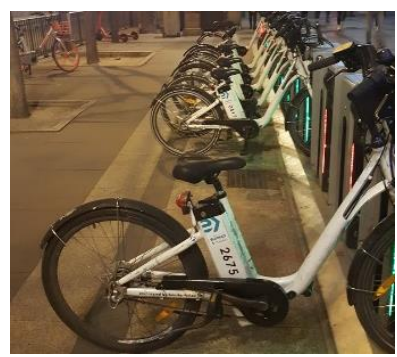

Source: Author (February 2020).

\section{Conclusions}

Although more and more cities around the world are adopting non-motorized sharing vehicles, we have noticed that this type of transport rarely allows access to children. This problem goes almost unnoticed in present-day cities. There are several limitations for the safe transportation of children, such as the minimum legal age allowed, the size of the vehicles, and the lack of accessories. It would be interesting to study these limitations as well as to understand how the cities could be benefited with more children and families with children using these services. What benefits for children, families and the city itself?

We conduct this study to contributing to a better city that is accessible to all and to promoting a reflection on this subject. Francesco Tonucci stated in his most recent book "if children to appropriate the city's public spaces [...] it will gain beauty, health and safety". (TONUCCI, 2019, p.155).

It is crucial to think about non-motorized vehicle sharing solutions that are also accessible to children and families with children. Promoting social inclusion in the city and access to non-motorized vehicle for all is a possibility that can become a new form of public transportation accessible also for low-income families and other residents. For this, this type of transportation must be available not only in urban centers but also in the suburbs. Furthermore, the city must have the conditions necessary to operate these vehicles safely. It could also be an opportunity for inclusion in the city for children, families with children, and tourists who are without access to their own vehicles. We believe that vehicle sharing can give children 
different experiences in the city, in a way that brings more benefits to themselves, adults, and the city itself.

\section{Acknowledgments}

To God to get here and make this dream come true. To Valmor Pazos, to the tutors Abner, Ederson, and Thiago, to the teachers from the Reabilita 9 , to the supervisor Marcos Thadeu, to the course colleagues, specially Thaís, to my friend Joana Costa and Ângela, for the help in the abstract translations. To my Brazilian friend who I met in Portugal and is currently in the beautiful city of Fortaleza, professor Eimard Nascimento, for the proofreading, formatting, and ABNT standardization, as well as the support given in the realization of this work. Finally, I thank all those who welcomed me, because I knew nothing and no one, in Brasilia, and I was so well received by everyone from the moment I arrived at the airport until the moment I left. I will never forget it. Thank you to everyone who works to make the Reabilita 9 happen! Thank you University of Brasilia for this opportunity!

\section{References}

AMERICAN ASSOCIATION OF RETIRED PERSONS. Would an E-Bike Get You Pedaling?, 2018. Disponível em https://www.aarp.org/livable-communities/getting-around/info-2018/e-bikes-energizebicycling.html. Acesso em 20 abr. 2020.

BIKE SHARING WORLD MAP. Global Map of Bikeshare by OOMap, 2020. Disponível em bikesharemap.com. Acesso em 28 mai. 2020.

CARVELO2GO. Wie funktioniert carvelo2go?, 2020. Disponível em https://www.carvelo2go.ch /de/. Acesso em 28 mai. 2020.

CHASE, R. Shared mobility priniciples for livable cities, 2017. Disponível em: https://www.sharedmobilityprinciples.org. Acesso em: 28 mai. 2020.

CHEN, E.; LIEROP,D.; ETTEMA, D.. Dockless bike-sharing systems: what are the implications?. Faculty of Geosciences e Utrecht University, 2020.

COLLINS, L. Bike Sharing for All. In Sharing Cities: Activating the Urban Commons. Editora: Shareable, California, 2018.

DEMAIO, P. Bike-sharing: History, Impacts, Models of Provision, and Future. Transportation, Vol. 12, №. 4, 2009.

DIJST, M., \& VIDAKOVIC, V.. Travel time ratio: The key factor of spatial reach. Transportation, Vol. 27, no 2, p. 179-199, 2000.

DURAN-RODAS, D.; WULFHORST, G.. Spatiotemporal objective and subjective factors influencing the usage of hybrid bike-sharing systems. Technical University of Munich, 2019.

ESPEGREN, H. M.. Why Norway's bike-sharing schemes outperform those in Sweden and Denmark, 2019. Disponível em https://www.thelocal.no/20190516/why-norways-bike-sharing-schemesoutperform-those-in-sweden-and-denmark. Acesso em: 28 mai. 2020.

GLOBAL MICROMOBILITY MAP. Global Micromobility Landscape, 2020. Disponível em: https://www.producthunt.com/posts/global-micromobility-landscape. Acesso em: 06 jun. 2020.

KATONA, G.; JUHASZ, J.. The History of the transport system development and future with sharing and autonomous systems (Department of Automotive Technologies, Faculty of Transportation 
Engineering and Vehicle Engineering), Budapest University of Technology and Economics. Hungary, 2020.

MAGALHÃES, M. Serviços urbanos e tecnologia. Brasília: Universidade de Brasília, 2018.

2019.

Material Didático do Módulo Mobilidade Urbana edição 9 do curso. Universidade de Brasília,

MERCHANT, C. How can D.C. make bikesharing family-friendly?. Washington, DC: DC Policy Center, 2019.

MOTOR24. A BUGA vai regressar a Aveiro com 200 bicicletas partilhadas, [Artigo] em 8/7/2019. Disponível em https://www.motor24.pt/pt-mobi-summit/a-buga-vai-regressar-a-aveiro-com-200bicicletas-partilhadas/661231/. Acesso em: 12 jun. 2020

NEXTBIKE. Transportrad Initiative Nachhaltiger Kommunen, 2020. Disponível em https://www.nextbike.de/de/norderstedt/tink/. Acesso em: 12 mai. 2020.

REIS, M. F. B. S. R. Por um bairro mais amigo das crianças: novos protagonistas. Dissertação de Mestrado (Departamento de Educação e Psicologia, Mestrado em Ciências da Educação - Educação Social e Intervenção Comunitária), Universidade de Aveiro, Portugal: Aveiro, 2015.

STADTWERKE KONSTANZ. Fahrrad-Mietsystem: Konrad + Tink, 2020. Disponível em https://www.stadtwerke-konstanz.de/mobilitaet/rad-mietsystem/. Acesso em: 20 mai. 2020.

TONUCCI, F. Por qué la infancia - sobre la necesidad de que nuestras sociedades apuesten definitivamente por las niños y los niños, Barcelona: Editorial Planeta, 2019.

TUROŃ, K.; CZECH, P.; TÓTH, J.. Safety and security aspects in shared mobility systems. Scientific Journal of Silesian University of Technology, 2019.

VELOCITTÀ. How this Amsterdam inventor gave bike-sharing to the world, 2014. Disponível em: http://velo-citta.eu/news/how-this-amsterdam-inventor-gave-bike-sharing-to-the-world/. Acesso em: 28 mai. 2020.

WORLD HEALTH ORGANIZATION. Global action plan on physical activity 2018-2030: more active people for a healthier world: at-a-glance. World Health Organization, 2018. Disponível em: https://apps.who.int/iris/handle/10665/272721. Acesso em: 28 mai. 2020.

\section{Margarete Filipa Barros Sousa Ribeiro Reis}

Master in Sciences Education: Social Education and Community Intervention from the University of Aveiro, post-graduated in Architecture and Urbanism from the University of Brasilia, graduated in Socioprofessional Education from the Piaget Institute. He has experience in projects related to urban planning with children, participation of children in the city and urban mobility for children and families with children. She has received an Erasmus+ scholarship in Portugal, Germany, Greece and Poland, where she has participated in three international projects.

Contribution of co-authorship: select among the options: theoretical-conceptual foundation and problematization; data research and statistical analysis; elaboration of figures and tables; Photos; elaboration and writing of the text; selection of references

\section{Marcos Thadeu Queiroz Magalhães}


Associate Professor at the Faculty of Architecture and Urbanism of the University of Brasilia. He was Professor in the Department of Transport Engineering and Geodesy at the Polytechnic School of the Federal University of Bahia. He holds a degree in Architecture and Urbanism from the Federal University of Bahia and a Master's and Doctorate in Transportation from the University of Brasilia. She was a fellow of JICA- Japanese International Cooperation Agency at the Comprehensive Urban Transportation Planning and Project Course, held in Tokyo/Japan. He served as Project Manager at the Ministry of Transport. Has experience in the area of Urban Planning and Transport Engineering, with emphasis on Transport Planning and Urban Mobility, working mainly on the following themes: Fundamentals and Planning Techniques

Contribution of co-authorship: (select among the options: theoretical-conceptual basis and problematization; data research and statistical analysis; elaboration of figures and tables; photos; elaboration and writing of the text; selection of bibliographic references; revision of the text.)

How to quote: REIS, Margarete Filipa Barros Sousa Ribeiro; MAGALHÃES, Marcos Thadeu Queiroz. Brazil, Portugal and Spain - analysis of non-motorized vehicle sharing services for children. Revista Paranoá. n.30, jan/jun 2021. DOI: 10.18830/issn.1679-0944. n.30.2021.08

Publisher in charge: Carolina Pescatori 